\title{
Classical nonlinear models to describe the growth curve for Murrah buffalo breed
}

\author{
Modelos não-lineares clássicos para descrever a curva de crescimento de búfalos da raça Murrah
}

\author{
Ronyere Olegário de Araújo ${ }^{\mathrm{I}}$ Cintia Righetti Marcondes ${ }^{I I}$ Maria Cecília Florisbal DaméIII \\ Analía del Valle Garnero ${ }^{\mathrm{IV}}$ Ricardo José Gunski ${ }^{\mathrm{IV}}$ Dionéia Magda Everling ${ }^{\mathrm{I}}$ \\ Paulo Roberto Nogara Rorato ${ }^{\mathrm{I}^{*}}$
}

\begin{abstract}
With the objective of to adjust nonlinear models for the growth curves for a buffaloes herd raised in floodable lands in Rio Grande do Sul state, monthly records measured from birth to two years-old of 64 males and 63 females born between 1982 and 1989 were used. The models used were: Von Bertalanffy, Brody, Gompertz and Logistic. The parameters were estimated by NLIN procedure and the criteria used to evaluate the adjustment given by the models were: asymptotic standard deviation; coefficient of determination; average absolute deviation of residues and asymptotic index. Von Bertalanffy and Brody models overestimated the male asymptotic weight (A) in 15.9 and $171.3 \mathrm{~kg}$, respectively, and the Gompertz and Logistic models underestimated it in 4.5 and $13.4 \mathrm{~kg}$, respectively. For females, the Logistic model underestimated the asymptotic weight $(-2.09 \mathrm{~kg})$, and Gompertz, Von Bertalanffy and Brody overestimated this parameter in $8.04,17.7$, and $280.33 \mathrm{~kg}$, respectively. The biggest average deviation was estimated by Brody model for both sexes, characterizing the biggest index. Considering the criteria, it is recommended the Gompertz and Logistic models for adjust females and males Murrah buffaloes breed growth curves.
\end{abstract}

Key words: asymptotic weight, buffalo, maturation rate.

\section{RESUMO}

Com o objetivo de ajustar modelos não-lineares ao crescimento ponderal para búfalos criados em terras baixas no Estado do Rio Grande do Sul, foram utilizados registros mensais mensurados do nascimento aos dois anos de idade de 64 machos e 63 fêmeas, nascidos no período de 1982 a 1989. Utilizaram-se os modelos: Von Bertalanffy, Brody, Gompertz e

\begin{abstract}
Logístico. Os parâmetros foram estimados usando o procedimento NLIN e os critérios utilizados para verificar o ajuste dos modelos foram: desvio padrão assintótico; coeficiente de determinação; desvio médio absoluto dos resíduos e o índice assintótico. Os modelos Von Bertalanffy $e$ Brody superestimaram o peso assintótico (A) para os machos em 15,9 e $171,3 \mathrm{~kg}$, respectivamente, e os modelos Gompertz e Logístico, subestimaram em 4,5 e 13,4kg, respectivamente. Para as fêmeas, o modelo Logístico subestimou o peso assintótico (-2,09kg) e os modelos Gompertz, Von Bertalanffy e Brody superestimaram esse parâmetro em: 8,$04 ; 17,7$ e $280,33 \mathrm{~kg}$, respectivamente. O maior desvio médio absoluto foi estimado pelo modelo Brody para ambos os sexos, caracterizando o melhor índice. Considerando os critérios, recomenda-se o modelo Gompertz e o modelo Logístico para ajustar a curva de crescimento de fêmeas e machos da raça Murrah.
\end{abstract}

Palavras-chave: bubalinos, peso assintótico, taxa de maturação.

\section{INTRODUCTION}

The knowledge and the control of animal's growth and development are themes that very much interest researches and breeders because of it permits to elaborate selection programs according to the growth traits inherent to each species to guide the nutritional management in order to have a more efficient system as well. Thus, it has been given so much attention to

IUniversidade Federal de Santa Maria (UFSM), Departamento de Zootecnia, 97105-900, Santa Maria, RS, Brasil. E-mail: rorato@smail.ufsm.br.*Autor para correspondência.

"Embrapa Pecuária Sudeste, São Carlos, SP, Brasil.

IIIEmbrapa Clima Temperado, Pelotas, RS, Brasil.

${ }^{\mathrm{I}}$ Universidade Federal do Pampa (UNIPAMPA), Campus de São Gabriel, São Gabriel, RS, Brasil. 
the animal growth curves, because they are related with the animal weight $(y)$ and age, and can be described by non-linear models that present parameters with biological interpretation (FITZHUGH JR., 1976).

Whereas to the zebu cattle (GARNERO et al., 2005), sheep (SARMENTO et al., 2006), and other animals (FREITAS, 2005) it is possible to find so many recent studies, a few are the researches about buffaloes with growth curve parameter estimate, which makes difficult its discussion. NOGUEIRA et al. (1998) observed that Brody model underestimated animals weight at the 720 days-old for Mediterranean buffalo breed, even presenting a good model adjustment to data, similar conclusions obtained by AGUDELOGÓMEZ et al. (2009) to multibreed buffalo herd raised in Colombia, in which it is reported that Brody and Gompertz models would describe in a more satisfactory way these animal growth curve. MALHADO et al. (2008) concluded that the Logistic model was the best at describing the growth curve for a Murrah buffalo breed raised in the Northeast Region of Brazil.

This research aims to identify which of the classical nonlinear models - Von Bertalanffy, Brody, Gompertz and Logistic models - better describe the growth curve of a Murrah buffalo breed raised in floodable lands in the State of Rio Grande do Sul.

\section{MATERIAL AND METHODS}

The data file corresponds to a group of 64 males and 63 females born between the period of 1982 and 1989, sired by three bulls and 42 cows. The register of the weight-age pairs were obtained by periodical weighing (approximately 28-day interval), performed since the birth until two years of age or 750 days old, totalizing 26 weighing per animal and 1,664 observation for males and 1,638 for females.

The traits assessed were asymptotic weight (A), which corresponds to the animal maturity weight and maturation rate $(K)$, that characterizes the speed in which the animal gets close to the adult weight. This parameter was stated using four classical mathematic nonlinear models: Von Bertalanffy $\left(Y_{t}=A\left(1-B e^{-K t}\right)^{3}+\varepsilon\right)$; Brody $\left(Y_{t}=A\left(1-B e^{-K t}\right)+\varepsilon\right)$; Gompertz $\left(Y_{t}=A e^{-B e^{\wedge}(-K t)}+\varepsilon\right)$ and Logistic $\left(Y_{t}=A\left(1+e^{-K t}\right)^{-M}+\varepsilon\right)$, in wich $Y$ represents the animal weight at a determined age $(t)$; $B$ is the integration constant to which initial weight is related (animal maturation rate at birth); $M$ is the parameter that shapes the curve; $e$ is the natural logarithm base; $\varepsilon$ represents the random error associated to each weighing. More information about these models see in OLIVEIRA et al. (2000).
The models parameters were estimated by Gauss Newton algorithm using NLIN procedure of Statistical Analysis System-SAS for Windows (SAS, 2001).

The criteria used to select the best growth curve model adjustment were: asymptotic standard deviation (ASD); graphic analyzes of curves observed and estimated; coefficient of determination $\left(\mathrm{R}^{2}\right)$ estimated according to SAMPAIO (2007); and the average absolute deviation (AAD), calculated in according to the function below

$$
\mathrm{AAD}=\frac{\sum_{\mathrm{i}=1}^{\mathrm{n}}\left[\mathrm{Yi}-\hat{\mathrm{Y}}_{\mathrm{i}}\right]}{\mathrm{n}}
$$

in wich: $Y i$ is the value observed; $\hat{Y} i$, the value estimated and $n$ the sample size. As smaller AAD value is, better the model adjustment gets.

For choosing the best model, an asymptotic index (AI) was created, like RATKOWSKY (1990) described. This author combined the ASD, AAD, and $\mathrm{R}^{2}$ criteria through the relationship $\mathrm{AI}=\mathrm{AAD}+\mathrm{ASD}$ $\mathrm{R}^{2}$; where the biggest estimates of each criterion was taken as the maximum value $(100 \%)$ and the others stated in relation to the former one. This way, as smaller AI is, better the model adjustment gets.

Once the best model was chosen, the absolute growth rate (AGR) was calculated. This rate is obtained from the first derivative of the best model to each sex in function of time $(\partial Y / \partial t)$, which allows to check graphically the diary growth rate of animals in a population (SARMENTO et al., 2006).

\section{RESULTS AND DISCUSSION}

The coefficients of determination $\left(\mathrm{R}^{2}\right)$ (Table 1 ) were high and equal to all the tested models. At the same time, small variations can be noticed when observing ASD, presenting the Brody model the smallest variation and the Logistic model the biggest. Although these variations are in small proportions, what makes impossible to assume any conclusion about the best model adjustment.

On the other hand, analyzing the average absolute deviation (AAD), it is noticed that the biggest value was estimate for Brody model, when compared to the other models. Fact that is confirmed by figure 1, indicating that this model could not be suitable to describe the average curve to Murrah breedmales. Taking this criterion in consideration, smaller deviations can be observed among Logistic and Gompertz models, followed by Von Bertalanffy.

The asymptotic weight $(A)$, according to BROWN et al. (1976), is not necessarily the animal's 
Table 1 - Parameters estimates (A, B, K and M) with their respective standard error (SE), and the criteria adopted to assess the model adjustment to females and males of Murrah breed.

\begin{tabular}{|c|c|c|c|c|c|c|c|c|}
\hline \multirow{2}{*}{ Model } & \multicolumn{4}{|c|}{ 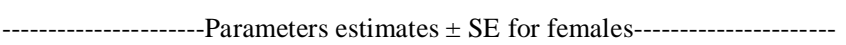 } & \multirow{2}{*}{ ASD } & \multirow{2}{*}{$\mathrm{R}^{2}$} & \multirow{2}{*}{$\mathrm{AAD}$} & \multirow{2}{*}{ AI } \\
\hline & $A(\mathrm{~kg})$ & $B$ & $K(\mathrm{~kg} / \mathrm{dia})$ & $M$ & & & & \\
\hline Von Bertalanffy & $426.8 \pm 4.1$ & $0.485 \pm 0.001$ & $0.0034 \pm 0.00003$ & - & 97.2 & 98.1 & 14.06 & 13.16 \\
\hline Brody* & $689.4 \pm 39.8$ & $0.911 \pm 0.001$ & $0.0020 \pm 0.00002$ & - & 94.8 & 98.2 & 100 & 96.6 \\
\hline Gompertz & $412.8 \pm 2.9$ & $1.866 \pm 0.005$ & $0.0041 \pm 0.00003$ & - & 98.5 & 98.1 & 10.76 & 11.16 \\
\hline Logistic & $403.9 \pm 2.6$ & - & $0.0049 \pm 0.00004$ & $2.540 \pm 0.007$ & 100 & 98.1 & 9.69 & 11.59 \\
\hline Model & $A(\mathrm{~kg})$ & $\begin{array}{c}\text { Parameters esti } \\
B\end{array}$ & $\begin{array}{c}\text { tes } \pm \mathrm{SE} \text { for males- } \\
\qquad\left(\mathrm{kg} \mathrm{dia}^{-1}\right)\end{array}$ & M & ASD & $\mathrm{R}^{2}$ & $\mathrm{AAD}$ & AI \\
\hline Von Bertalanffy & $458.1 \pm 5.8$ & $0.483 \pm 0.001$ & $0.0041 \pm 0.00003$ & - & 97.66 & 99.9 & 26.09 & 23.86 \\
\hline Brody* & $613.5 \pm 21.0$ & $0.908 \pm 0.001$ & $0.0024 \pm 0.00003$ & - & 95.76 & 100 & 100 & 95.76 \\
\hline Gompertz & $437.7 \pm 3.5$ & $1.854 \pm 0.005$ & $0.0047 \pm 0.00004$ & - & 98.70 & 99.8 & 18.34 & 17.15 \\
\hline Logistic & $428.8 \pm 2.8$ & - & $0.0069 \pm 0.00004$ & $4.089 \pm 0.006$ & 100 & 99.8 & 16.91 & 17.12 \\
\hline
\end{tabular}

ASP = Asymptotic Standard Deviation in \%; $\mathrm{R}^{2}=$ Coefficient of determination in \%; AAD = Average Absolute Deviation of residues in \%; $\mathrm{AI}=$ Asymptotic Index; *Two males and three females did not reach convergence.

adult weight, but it is the average weight to be reached during adult phase, independently of seasonal conditions. The values estimated by all the models to this parameter, both for males and females (Table 1), were inferior than the ones reported by MALHADO et al. (2008), presenting, consequently, bigger rate of maturation $(K)$; nevertheless, it must be taken in consideration a bias caused by the non-separation of animals in function of sex by these authors. The Brody model was the function that estimated the biggest $A$ (689.4 and 613.5kg to females and males, respectively), and the smaller value was obtained by Logistic model (403.9 and 428.8kg to females and males, respectively), similar results was reported by MALHADO et al. (2008) and other authors considering zebu cattle (PEROTTO et al., 1992; OLIVEIRA et al., 2000).

The $K$ parameter represents the maturation rate and indicates the growth speed in achieving the asymptotic weight from initial weight. As bigger $K$ value is, faster the animal gets close to its asymptotic weight, i. e., bigger the growth speed is (GARNERO et al., 2005). The Logistic model, for both females and males, estimated the biggest $K$ value $(0.0049$ and $0.0069 \mathrm{~kg}$ $\mathrm{day}^{-1}$, females and males, respectively) and the smaller one was obtained by Brody model ( 0.0020 and $0.0024 \mathrm{~kg}$ day $^{-1}$, females and males, respectively). As an example, STEWART \& MARTIN (1981), for Angus breed animals, obtained $K$ value equal to 0.058 and $0.066 \mathrm{~kg}$ day $^{-1}$ to the Shorthorn breed animals; and MARSHALL et al. (1984), to Red Poll breed animals, obtained 0.059. BARBOSA et al. (2002) reported $K$ value equal to 0.056kg day ${ }^{-1}$, using the Von Bertalanffy model for a Canchin breed herd. GARNERO et al. (2005), having used the Brody model to adjust Nellore breed female data, obtained the average $K$ value equal to $0.0045 \mathrm{~kg}$ day $^{-1}$. All these results demonstrate how late these species are, both for males and females, when compared to zebu cattle in a general way.

In an increasing sequence, Von Bertalanffy, Gompertz, Brody and Logistic models overestimated the weight at birth (WB) for females in 28.55, 32.77, 42.70, and 43.45kg (Figure 1); and for males, Brody, Von Bertalanffy, Gompertz, and Logistic models overestimated in 28.35, 29.14, 32.16, and 38.13kg (Figure 1). According to FREITAS (2005), it seems there to be a tendency of nonlinear models to overestimate the birth weight, though in his research about Canchim breed cattle growth, he found that Brody, Von Bertalanffy, Gompertz, and Logistic models overestimated this trait. The possible cause of frequent overestimation of this feature is the use of asymptotic weight to estimate the weight of animals in a pre-determined period.

It is observed that the non-linear model Von Bertalanffy (Figure 1) and Brody (Figure 1) tend to overestimate all the weights observed for both females and males. It is worthy to highlight that the biggest overestimation to females occurred from the Von Bertalanffy at the 549 days-old, when the weight observed was overestimated in $18 \%$, which represents $58 \mathrm{~kg}$. Related to males (Figure 1), the biggest overestimation occurred at 578 days-old, when the value observed was overestimated in $22 \%$, which represents $76.3 \mathrm{~kg}$. 

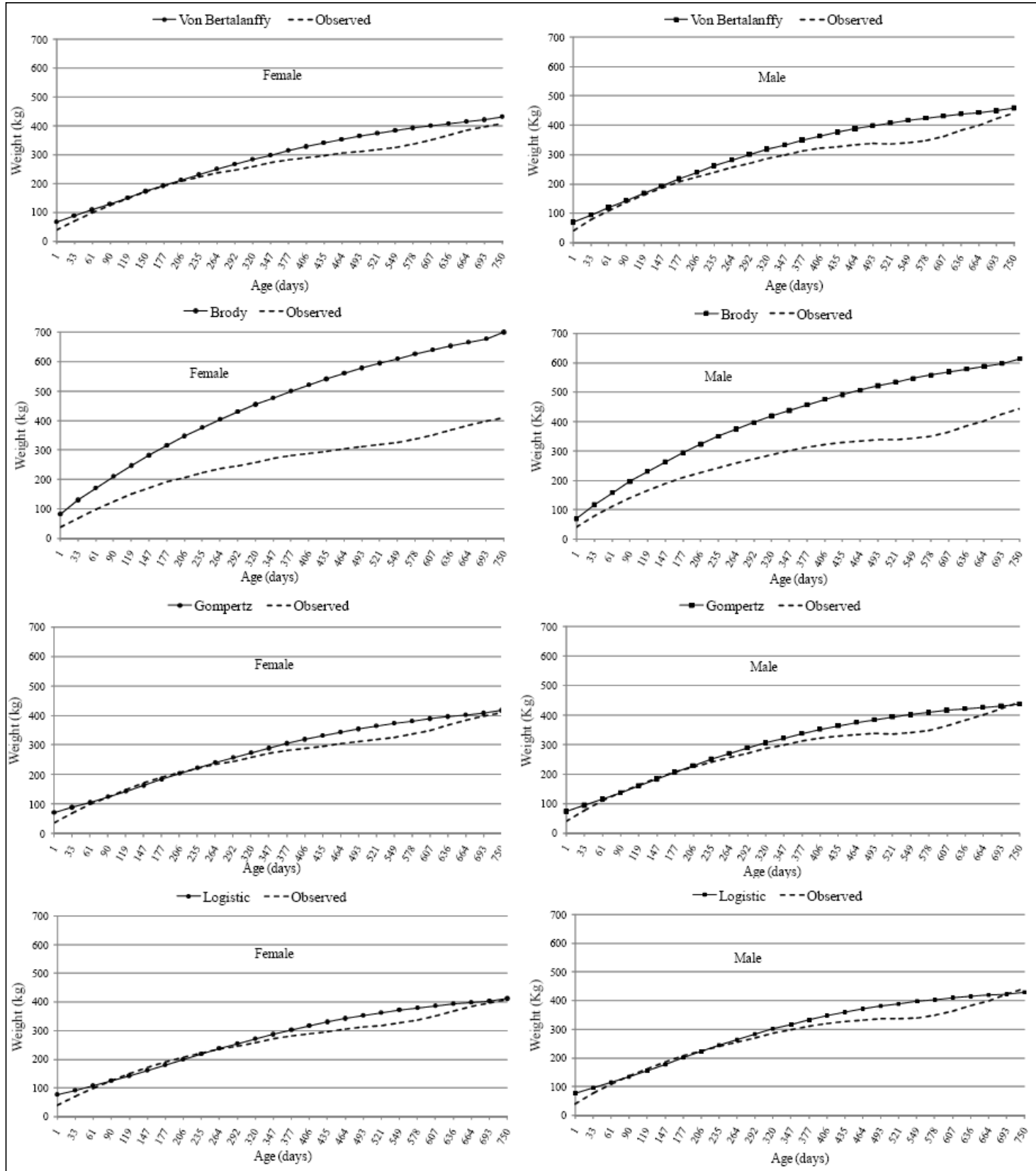

Figure 1 - Growth curve (females and males) obtained by the avarage of weight observed and by weight stated by Von Bertalanffy, Brody, Gompertz and Logistic models to diferent ages.

In Brody model adjusment, the biggest overestimation to females in absolute value occurred at 750 days-old, when the weight observed was overestimated in $71 \%$, which represents $291 \mathrm{~kg}$; and the biggest in magnitude occurred to birth weight (BW), with a overestimation corresponding to $43 \mathrm{~kg}$ and representing $112 \%$ of the value observed (Figure 1 ). It is observed that the biggest overestimation occurred at 578 days-old, when the observed value was overestimated in $60 \%$, that represents $210.1 \mathrm{~kg}$.
At the period before weaning (199 to 206 days old), and differently from the previous models (Von Bertalanffy and Brody models), the Gompertz model (Figure 1) underestimated the weights in this period; the biggest underestimation was $-8 \mathrm{~kg}$ at 174 days-old, that represents $-4 \%$ of the value observed at this age for females. On the other hand, all the other points of the curve were overestimated: the biggest absolute value was $47 \mathrm{~kg}$ at 549 days-old, that represents $15 \%$ of the value observed at this age. In relation to 
weights at 750 days-old, the overestimation was $8 \mathrm{~kg}$, representing $2 \%$ of the value observed to this age.

For males, at the period before weaning (177 days-old), the Gompertz model (Figure 1) underestimated the weight observed in $3.9 \mathrm{~kg}$ and the Logistic model in $8.6 \mathrm{~kg}$, representing $2 \%$ and $5 \%$, respectively; and in weight at 750 days of age (W750), the Gompertz model underestimated this measure in $4.5 \mathrm{~kg}$ and the Logistic model (Figure 1) in $13.4 \mathrm{~kg}$, what represents $1.7 \%$ and $3.5 \%$, respectively, of the value observed.

Similarly to what occurred for males at the Von Bertalanffy and Brody models, the Gompertz and Logistic models overestimated in a bigger degree the 578 days-old. The Gompertz model overestimated this measure in $17 \%$, which corresponds to $60 \mathrm{~kg}$ of the observed weight; and the Logistic model overestimated in $16 \%$, corresponding to $55.7 \mathrm{~kg}$. This age coincides with the second winter of these animals and, differently of the first winter, in this one they depend only on their potential to keep on gaining/maintaining weight with the forage decrease.

Based on AI (Table 1) and on the behavior view of the curves predicted (Figure 1), it is noticed that the Gompertz and Logistic model were the ones that had the best model adjustment of the growth curve for Murrah breed females and males, respectively. In both cases, the Gompertz model for males and the Logistic model for females were suitable for the adjustment, besides, Von Bertalanffy for both sexes. These results are partially in agreement with the ones related by MALHADO et al. (2008), who concluded that the Logistic model presented better adjustment at describing only one growth curve to both sexes of the same breed raised in Brazilian Northeast. However, the findings do not match to the ones obtained by
AGUDELO-GÓMEZ et al. (2009), to multibreed herd, they recommend the Brody model to describe the growth curve of animals.

The Absolute growth rate (AGR) (Figure 2), originated since the first derivative from the Gompertz model to females and from Logistic model to males, was increased until a certain peak, around 0.690 and $0.800 \mathrm{~kg}$ per day $\left(K . A^{-1}\right)$ to females and males respectively; decreasing afterward with age increase. It is noticed that the maximum point, that represents the age when the curve changes from increase to decrease (peak), was obtained, to females at 177 days old $\left(K^{-1}\right)$ with approximately $172 \mathrm{~kg}\left(A^{-1}\right)$; and at 147 days old to males with approximately $186 \mathrm{~kg}\left(A^{-1}\right)$, showing that the peak growth rate was obtained very early in both sexes.

SARMENTO et al. (2006) highlight that this behavior can indicate that the animals have adapted themselves to the environment which they were exposed to, acquiring this kind of growth pattern, i. e, with bigger growth rate at younger ages and slower rates at older ages, providing lighter weights to maturity.

The AGR in the end of the period studied varied from 0.11 to females to $0.150 \mathrm{~kg}$ per day to males, showing that since 40 months-old, the weight gain is very small.

\section{CONCLUSION}

Considering the models used in this study, the Gompertz and the Logistic are those that better adjusted the growth curve of Murrah breed females and males. However, more studies must be done using other models, such as the segmented regression, to get a more efficient adjustment in order to fit the data for the period of winter. Studies of equality among parameters in non-linear regression models are advisable in order to obtain a unique model to describe the growth curve to both sexes for this specie.
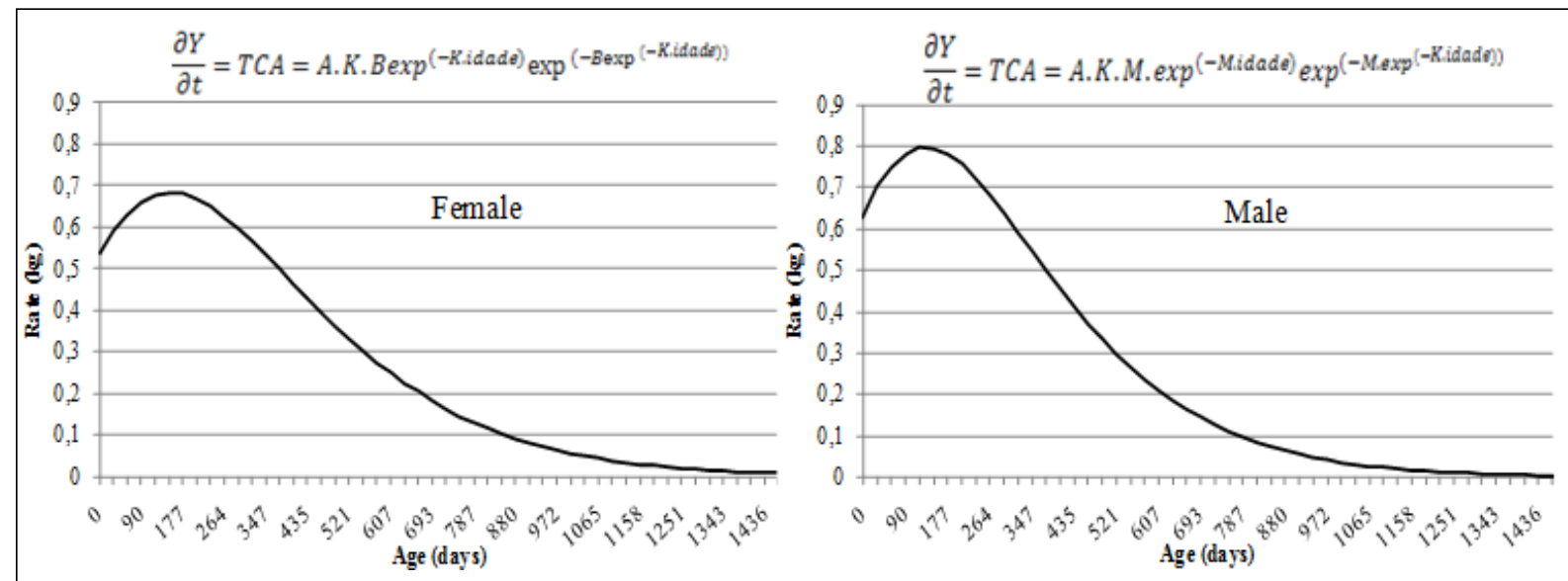

Figure 2 - Absolute growth rate (AGR) stated by Gompertz model to female and by Logistic model to males. 


\section{REFERENCES}

AGUDELO-GÓMEZ, D.A. et al. Growth curves and genetic parameters in Colombian Buffaloes (Bubalus bubalis Artiodactyla, Bovidae). Revista Colombiana de Ciencias Pecuarias, v.22, p.178-188, 2009. Available from: <http://rccp.udea.edu.co/ index.php/ojs/article/view/389>. Accessed: Dez. 1, 2009.

BARBOSA, P.F. et al. Peso à maturidade, taxa de maturação e eficiência produtiva em fêmeas da raça Canchim. Arquivo Brasileiro de Medicina Veterinária e Zootecnia, v.54, p.510-517, 2002. Available from: <http://www.scielo.br/ s ci el o.ph p ? c c ri p t = s ci_art t ext \& pid = S 0102 $09352002000500009 \& \operatorname{lng}=p t \& n r m=i s o \& t \operatorname{lng}=p t>$. Accessed: Jul. 21, 2009. doi: 10.1590/S0102-09352002000500009.

BROWN, J.E. et al. A comparison of nonlinear models for describing weight-age relationships in cattle. Journal of Animal Science, v.42, p.810-818, 1976. Available from: < h t t p :// j a s.f a s s.org / c g i / r e print / $42 / 4 /$ 810?maxtoshow=\&hits=10\&RESULTFORMAT $=$ \&author1=Brown,$+\mathrm{J}$ E\&searchid=1\&FIRSTINDEX=0\&resourcetype $=$ HWCIT $>$. Accessed: Ago. 15, 2009.

FITZHUGH JR., H.A. Analysis of growth curves and strategies for altering their shape. Journal of Animal Science, v.42, p.10361051, 1976. Available from: <http://jas.fass.org/cgi/reprint/42/4/ 1036? maxtoshow=\&hits=10\&RESULTFORMAT=\&author1=Fitzhugh, +H.A.\&searchid=1 \&FIRSTINDEX=0\&resourcetype=HWCIT>. Accessed: Ago. 15, 2009.

FREITAS, A.R. Curvas de crescimento na produção animal. Revista Brasileira de Zootecnia, v.34, p.786-795, 2005 Available from: <http://www.scielo.br/pdf/rbz/v34n3/ a10v34n3.pdf $>$. Accessed: Abr. 10, 2008. doi: 10.1590/S151635982005000300010 .

GARNERO, A. Del V. et al. Parâmetros genéticos da taxa de maturação e do peso assintótico de fêmeas da raça Nelore. Arquivo Brasileiro de Medicina Veterinária e Zootecnia, v.57, p.652-662, 2005. Available from: <http://www.scielo.br/ s c i e l o.ph p ? s c r i p t = s c i _ p d f \& p i d = S 0102 $09352005000500011 \& \operatorname{lng}=p t \& n r m=i s o \& t \operatorname{lng}=p t>$. Accessed: Abr. 10, 2008. doi: 10.1590/S0102-09352005000500011.

MALHADO, C.H.M. et al. Modelos no lineales para describir el crecimiento de bufalinos de la raza Murrah. Archivos de Zootecnia, v.57, p.497-503, 2008. Available from: <http:// www.uco.es/organiza/servicios/publica/az/az.htm>. Accessed: Fev. 10, 2009.
MARSHALL, T.E. et al. Relationship of lifetime productivity with mature weight and maturation rate in Red Poll cows. Animal Production, v.39, p.383-387, 1984. Available from: < h t t p : / / journals. c a mbridge.org / a c ti o n / displayAbstract fromPage $=$ online $\&$ aid $=7373764>$. Accessed: Abr. 10, 2008

NOGUEIRA, J.R. et al. Estimativas de parâmetros de curvas de crescimento de búfalos da raça Mediterrâneo. In: REUNIÃO ANUAL DA SOCIEDADE BRASILEIRA DE ZOOTECNIA, 35., 1998, Botucatu, SP. Anais... Botucatu: SBZ, 1998. p.374-376.

OLIVEIRA, H.N. et al. Comparação de modelos não lineares para descrever o crescimento de fêmeas da raça Guzerá. Pesquisa Agropecuária Brasileira, v.35, p.1843-1851, 2000. Available from: <http://www.scielo.br/pdf/pab/v35n9/ v35n9a17.pdf>. Accessed: Ago. 13, 2008. doi: 10.1590/S0100$204 \times 2000000900017$.

PEROTTO, D. et al. Comparison of nonlinear functions for describing the growth curve of three genotypes of dairy cattle. Canadian Journal of Animal Science, v.72, p.773-782, 1992. Available from: <http://pubs.aic.ca/doi/abs/10.4141/cjas92089>. Accessed: Out. 12, 2008. doi: 10.4141/cjas92-089.

RATKOWSKY, D.A. Handbook of nonlinear regression models. New York and Basel: Marcel Dekker, 1990. 241p.

SAMPAIO, I.B.M. Estatística aplicada à experimentação animal. 3.ed. Belo Horizonte: FEPMVZ, 2007. 264p.

SARMENTO, J.L.R. et al. Estudo da curva de crescimento de ovinos Santa Inês. Revista Brasileira de Zootecnia, v.35, p.435-442, 2006. Available from: <http://www.scielo.br/pdf/ rbz/v35n2/a14v35n2.pdf>. Accessed: Abr. 10, 2008.

SAS Institute Inc. Statistical Analysis System user's guide. Version 8.2 ed. Cary, 2001. 943p.

STEWART, T.S.; MARTIN, T.G. Mature weight, maturation rate, maternal performance and their interrelationships in purebred and crossbred cows of Angus and Milking Shorthorn parentage. Journal of Animal Science, v.52, p.51-56, 1981. Available from: <http://jas.fass.org/cgi/reprint/52/1/ 51?maxtoshow=\&hits=10\&RESULTFORMAT=\&author1=Stewart,+T.S. \&searchid $=1 \&$ FIRSTINDEX $=0$ \&resourcetype $=$ HWCIT $>$. Accessed: Set. 25, 2009. 